JURNAL RISET MAHASISWA AKUNTANSI (JRMA)

Volume IX, No. 1, Tahun 2021

e-ISSN : 2715 - 7016

\title{
PENGARUH LIKUIDITAS DAN PERPUTARAN PERSEDIAAN TERHADAP RETURN ON ASSETS (ROA) DENGAN PERTUMBUHAN PENJUALAN SEBAGAI VARIABEL MODERASI PADA PERUSAHAAN MAKANAN DAN MINUMAN PERIODE 2015-2018
}

\author{
Dio Irsa Asy Sams \\ e-mail: dioirsa.sams@gmail.com
}

\begin{abstract}
Abdul Halim
Ati Retna Sari

Program Studi Akuntansi Fakultas Ekonomika dan Bisnis Universitas PGRI Kanjuruhan Malang
\end{abstract}

\begin{abstract}
Abstrak
Penelitian ini bertujuan untuk menguji dan menjelaskan pengaruh likuiditas dan perputaran persediaan terhadap nilai perusahaan dengan pertumbuhan penjualan sebagai variabel moderasi pada perusahaan makanan dan minuman yang terdaftar di Bursa Efek Indonesia periode tahun 20152018. Jenis penelitian yang digunakan adalah explanatory research, dengan pengujian asumsi klasik, dan dianalisis menggunakan analisis regresi moderasian, serta menggunakan uji t. Jumlah sampel sebesar 11 perusahaan, dan metode pengambilan anggota sampel yang digunakan yaitu purposive judgment sampling. Variabel penelitian ini terdiri dari likuiditas dan perputaran persediaan sebagai variabel independen, return on assets (ROA) sebagai variabel dependen, dan pertumbuhan penjualan sebagai variabel moderasi. Hasil analisis menunjukkan bahwa secara parsial likuiditas dan perputaran persediaan berpengaruh terhadap return on assets (ROA), dan pertumbuhan penjualan memperkuat pengaruh likuiditas dan perputaran persediaan terhadap return on assets (ROA).
\end{abstract}

Kata kunci : Likuiditas, Perputaran Persediaan, Pertumbuhan Penjualan, dan Return On Assets (ROA)

\section{Abstract}

This study aims to examine and explain the effect of liquidity and inventory turnover on firm value with sales growth as a moderating variable in food and beverage companies listed on the Indonesia Stock Exchange for the period 2015-2018. This type of research is explanatory research, with classical assumption testing, and analyzed using moderated regression analysis, and using the $t$ test. The sample size is 11 companies, and the sampling method used is purposive judgment sampling. The variables of 
this study consist of liquidity and inventory turnover as independent variables, return on assets (ROA) as the dependent variable, and sales growth as a moderating variable. The results of the analysis show that partially liquidity and inventory turnover have an effect on return on assets (ROA), and sales growth strengthens the effect of liquidity and inventory turnover on return on assets (ROA).

Keywords Liquidity, Inventory Turnover, Sales Growth, and Return On Assets (ROA)

\section{PENDAHULUAN}

Industri makanan dan minuman diproyeksi masih menjadi salah satu sektor andalan penopang pertumbuhan manufaktur dan ekonomi nasional pada tahun depan. Peran penting sektor strategis ini terlihat dari kontribusinya yang konsisten dan signfikan terhadap produk domestik bruto (PDB) industri non-migas serta peningkatan realisasi investasi. Menurut Nafarin (2007: 231), peranan laba adalah efesiensi usaha setiap perusahaan sekaligus merupakan suatu kekuatan pokok agar perusahaan dapat tetap bertahan untuk jangka pendek dan jangka panjang perusahaan. Pentingnya laba juga tercermin dari rasio Return on assets (ROA). Sementara itu likuiditas adalah salah satu hal yang mempunyai pengaruh terhadap profitabilitas perusahaan, karena tinggi rendahnya tingkat likuiditas suatu perusahaan akan menentukan dan mempengaruhi kinerja perusahaan menjalankan aktivitas untuk memperoleh laba. Menurut hani (2015:121), likuiditas adalah kemampuan suatu perusahaan dalam memenuhi semua kewajiban keuangan yang segera dapat dicairkan atau yang sudah jatuh tempo. Di lain pihak, pemanfaatan komponen aktiva juga mempengaruhi profitabilitas perusahaan. Andrianis (2010) berpendapat Profitabilitas perusahaan yang maksimal diperoleh melalui pemanfaatan komponen aktiva yang dimiliki perusahaan seperti kas, persediaan, piutang dan komponen aktiva lainnya secara efisien dan efektif. Tingkat efektivitas dan efisiensi penggunaan sumber daya (assets) perusahaan dapat diukur melalui rasio aktivitas. Perputaran persediaan (Inventory Turnover) merupakan salah satu jenis rasio aktivitas yang menggambarkan akan liquiditas dari perusahaan, yakni dengan cara mengukur efisiensi sebuah perusahaan dalam mengelola dan menjual persediaan yang dimiliki perusahaan. Menurut Hanafi dan Halim, 2000:80, adanya perputaran persediaan yang tinggi menandakan semakin tingginya persediaan berputar dalam satu tahun, hal ini menandakan adanya efektifitas manajemen persediaan.

Penelitian tentang variabel yang mempengaruhi profitabilitas perusahaan telah dilakukan diantaranya; Sanjaya (2015) Berdasarkan hasil analisis regresi linier berganda untuk pengaruh likuiditas dan aktivitas terhadap profitabilitas. Current ratio, total assets turnover ratio dan working 
capital turnover ratio berpengaruh tidak signifikan terhadap profitabilitas yang diproksikan dengan return on assets. Penelitian Sihombing (2017) menyimpulkan bahwa likuiditas berpengaruh positif dan aktivitas berpengaruh negatif terhadap profitabilitas Likuiditas dan aktivitas berpengaruh signifikan terhadap profitabilitas. Wulandari,Gultom (2018) menyimpulkan secara parsial current ratio dan pertumbuhan penjualan tidak berpengaruh terhadap Return on Assets. Amrita Rahmah, Cipta, Yudiaatmaja (2016) menyimpulkan Ada pengaruh yang positif dan signifikan secara simultan dari Likuiditas (X1), Solvabilitas (X2) dan Aktivitas (X3) terhadap Profitabilitas (Y).

Beberapa hasil penelitian terdahulu terdapat hasil penelitian yang tidak konsisten terkait likuiditas dan aktivitas terhadap profitabilitas. Karena terdapat hasil penelitian terdahulu yang tidak konsisten, peneliti menambahkan satu variabel baru yaitu pertumbuhan penjualan sebagai variabel moderasi yang di duga dapat memperkuat ataupun memperlemah pengaruh likuiditas dan aktivitas terhadap profitabilitas perusahaan. Analisis yang akan digunakan yaitu analisis regresi moderasiam yang akan menjelaskan dan menguji pengaruh variabel independen terhadap variabel dependen dengan varibael moderasi, sehingga judul penelitian ini yaitu " Pengaruh Likuiditas dan Perputaran Persediaan Terhadap Return On Assets (ROA) dengan Pertumbuhan Penjualan Sebagai Variabel Moderasi ( Studi Kasus Pada Perusahaan Manufaktur yang Terdaftar di Bursa Efek Indonesia Tahun 2015-2018)"

\section{TINJAUAN PUSTAKA}

\section{Profitabilitas}

Halim (2015) profitabilitas adalah ukuran sampai seberapa besar efektivitas manajemen dalam mengelola aset dan modal yang dimiliki perusahaan untuk menghasilkan laba dari aktivitas yang dilakukan perusahaan pada periode akuntansi tertentu.

\section{Return On Assets}

Kasmir (2010) merupakan rasio untuk mengukur laba bersih sesudah pajak dengan total aset yang dimiliki. Semakin tinggi rasio ini berarti dengan jumlah aktiva yang sedikit dapat menghasilkan laba yang besar, dan sebaliknya.

\section{Likuiditas}

Syamsuddin (2001 : 41 ) menyatakan bahwa likuiditas merupakan indikator mengenai kemampuan perusahaan untuk membayar semua kewajiban finansil jangka pendek pada saat jatuh tempo dengan menggunakan aktiva lancar yang tersedia. 


\section{Perputaran Persediaan}

Rasio perputaran persediaan digunakan untuk mengukur aktivitas atau likuiditas dari persediaan perusahaan. Maksudnya yaitu mengukur tingkat efisiensi suatu perusahaan dalam mengelola dan menjual persediaan yang dimiliki oleh perusahaan. Menurut Kasmir (2010:264) persediaan adalah sejumlah barang yang harus disediakan oleh perusahaan pada suatu tempat tertentu. Artinya adanya sejumlah barang yang disediakan perusahaan guna memenuhi kebutuhan produksi atau penjualan barang dagangan.

\section{Pertumbuhan Penjualan}

Pertumbuhan penjualan mencerminkan keberhasilan investasi periode masa lalu dan dapat dijadikan sebagai prediksi pertumbuhan masa yang akan datang. Pertumbuhan penjualan merupakan indikator permintaan dan daya saing perusahaan dalam suatu industri. Menurut Kesuma (2009) juga menyatakan bahwa sales growth adalah kenaikan jumlah penjualan dari tahun ke tahun atau dari waktu ke waktu.

\section{Hipotesis Penelitian}

1. Pengaruh Likuiditas Terhadap ROA (Return On Assets)

Likuiditas mempunyai pengaruh terhadap profitabilitas perusahaan, karena tinggi rendahnya tingkat likuiditas suatu perusahaan akan menentukan dan mempengaruhi kinerja perusahaan menjalankan aktivitas untuk memperoleh laba. Pernyataan ini di dukung penelitian yang dilakukan oleh Sihombing (2017) menyimpulkan bahwa Likuiditas berpengaruh positif signifikan terhadap profitabilitas. Rahmawati (2017) menyimpulkan Hasil penelitian menunjukkan bahwa secara parsial terdapat hubungan signifikan likuiditas terhadap profitabilitas. Sementara penelitian Wulandari, Gultom (2018) bertolak belakang dengan penelitian sebelumnya dengan menyimpulkan bahwa likuiditas tidak berpengaruh terhadap profitsbilitas. Berdasarkan uraian tersebut hipotesis pertama dalam penelitian ini ditentukan sebagai berikut:

H1 : Likuiditas secara parsial berpengaruh terhadap ROA (Return On Assets).

2. Pengaruh Aktivitas Terhadap ROA (Return On Assets)

Semakin efektif dan efisien kemampuan bisnis suatu perusahaan untuk mengubah berbagai jenis aset atau aktivanya, maka perusahaan tersebut akan cenderung menjadi perusahaan yang menguntungkan atau perusahaan yang memiliki profitabilitas yang tinggi. Hasil penelitian oleh Indah kusuma wardani,dkk (2018) menyimpulkan bahwa variabel Aktivitas secara parsial berpengaruh positif dan signifikan terhadap Profitabilitas. Sihombing (2017) menyimpulkan bahwa 
aktivitas berpengaruh signifikan terhadap profitabilitas. Wardhani,dkk (2018) menyimpulkan aktivitas secara parsial berpengaruh signifikan positif terhadap profitabilitas perusahaan. Di lain pihak Setyawan, susilowati (2018) menyimpulkan perputaran modal kerja secara parsial tidak berpengaruh terhadap profitabilitas. Berdasarkan uraian tersebut hipotesis kedua dalam penelitian ini ditentukan sebagai berikut:

H2 : Aktivitas secara parsial berpengaruh terhadap ROA (Return On Assets).

3. Pengaruh Likuiditas Terhadap ROA (Return On Assets) Dengan Pertumbuhan Penjualan Sebagai Variabel Moderasi

Penjualan menghasilkan kas atau piutang, sehingga semakin besar pertumbuhan penjualan maka semakin besar pula aset lancar yang dapat digunakan untuk membiayai kewajiban perusahaan. Semakin tingginya tingkat likuiditas perusahaan maka profitabilitas perusahaan juga akan mengalami peningkatan karena tingkat likuiditas berpengaruh terhadap profitabilitas. Pernyataan ini di dukung penelitian yang dilakukan oleh Natania (2016) menyimpulkan Pertumbuhan penjualan berpengaruh positif signifikan terhadap likuiditas. Sihombing (2017) menyimpulkan bahwa Likuiditas berpengaruh positif signifikan terhadap profitabilitas. Di pihak lain Wulandari, Gultom (2018) menyimpulkan secara parsial Current Ratio dan pertumbuhan penjualan tidak berpengaruh terhadap Return On Assets (ROA). Rahmawati (2017) menyimpulkan secara parsial tidak terdapat hubungan signifikan antara pertumbuhan penjualan terhadap profitabilitas. Berdasarkan uraian tersebut hipotesis ketiga dalam penelitian ini ditentukan sebagai berikut:

H3 : Pertumbuhan penjualan memperkuat pengaruh likuiditas terhadap ROA (Return On Assets).

4. Pengaruh Aktivitas Terhadap ROA (Return On Assets) dengan Pertumbuhan Penjualan Sebagai Variabel Moderasi

Peningkatan pertumbuhan penjualan berpengaruh terhadap perputaran persediaan. Karena, jika ppertumbuhan penjualan meningkat maka aktivitas perputaran persediaan juga akan meningkat. Tentunya hal tersebut mempengaruhi tingkat profit perusahaan meningkat juga. Pernyataan ini di dukung penelitian yang dilakukan oleh Gaur, Kesavan (2007) menyimpulkan pertumbuhan penjualan berpengaruh positive terhadap aktivitas. Sihombing (2017) menyimpulkan bahwa aktivitas berpengaruh signifikan terhadap profitabilitas. Di lain pihak Sanjaya (2015) menyimpulkan Current ratio, total assets turnover dan working capital turnover ratio berpengaruh tidak signifikan terhadap prfitabilitas. Setyawan, susilowati (2018) menyimpulkan perputaran modal kerja secara parsial tidak berpengaruh terhadap profitabilitas. Rahmawati (2017) menyimpulkan bahwa secara parsial tidak 
Dio Irsa Asy Sams, Pengaruh Likuiditas Dan Perputaran PersediaAn Terhadap Return On Assets

(Roa) Dengan Pertumbuhan Penjualan Sebagai Variabel Moderasi Pada Perusahaan Makanan Dan

MinUMAN PERIODE 2015-2018

terdapat hubungan signifikan antara pertumbuhan penjualan terhadap profitabilitas. Berdasarkan uraian tersebut hipotesis keempat dalam penelitian ini ditentukan sebagai berikut:

H4 : Pertumbuhan penjualan memperkuat pengaruh aktivitas terhadap ROA (Return On Assets).

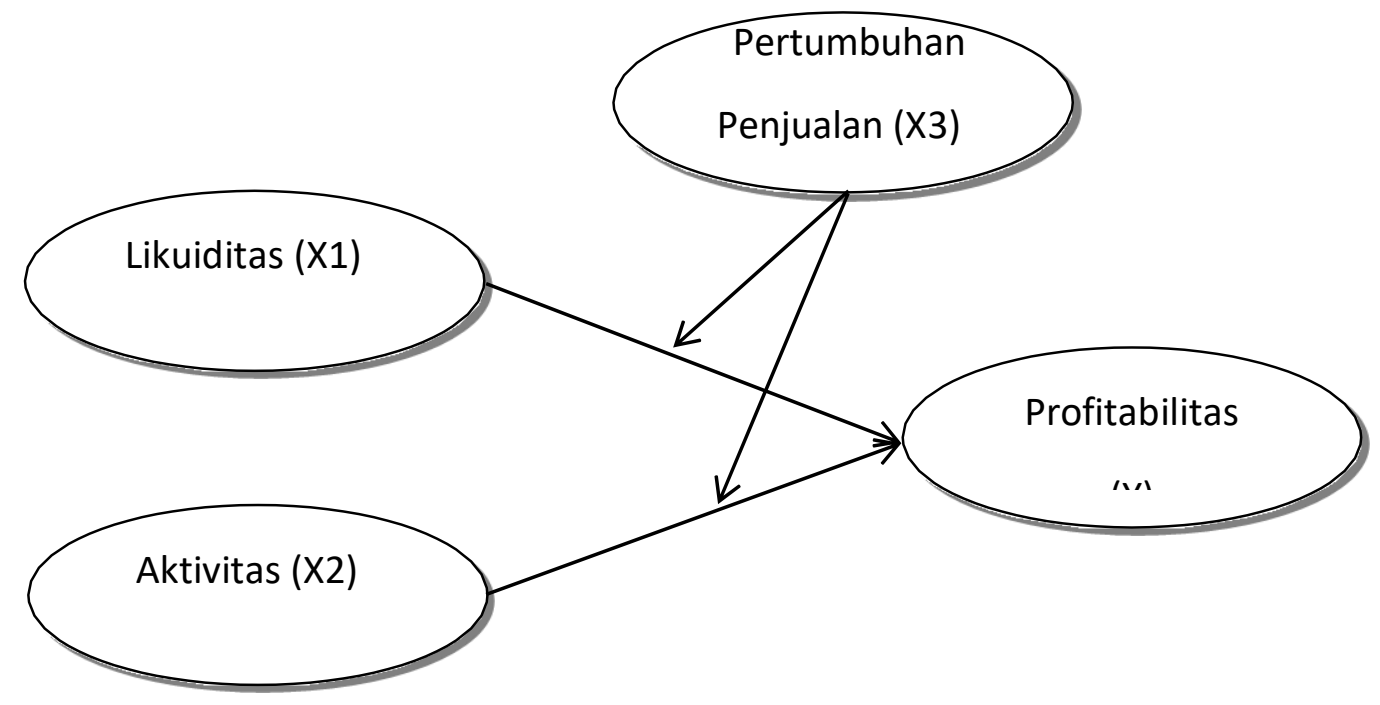

Gambar 2.1 Kerangka Konsep

\section{METODE}

Jenis data yang digunakan yaitu data sekunder berupa laporan keuangan perusahaan makanan dan minuman pada tahun 2015-2018. Metode pengumpulan data berupa dokumentasi dengan mengakses www.idx.co.id. Populasi penelitian yaitu seluruh perusahaan makanan dan minuman yang terdaftar di BEI periode tahun 2015-2018. Teknik pengambilan anggota sampel menggunakan purposive judgment sampling, yang merupakan penentuan anggota sampel dengan kriteria-kriteria tertentu, yaitu 1) Perusahaan makanan dan minuman yang terdaftar di BEI pada tahun 2015-2018. 2) Perusahaan makanan dan minuman yang mempublikasikan laporan keuangan secara berturut-turut pada tahun 2015-2018 di BEI. 3) Perusahaan manufaktur yang memperoleh laba pada periode 2015- 2018. 4) Perusahaan manufaktur yang mengalami pertumbuhan penjualan. 5) Perusahaan makanan dan minuman yang mempublikasikan laporan keuangannya dengan menggunakan mata uang rupiah pada periode 2015-2018.

\section{Definisi Operasional Variabel}

1. Variabel Dependen 
Variabel dependen yang digunakan dalam penelitian ini adalah nilai perusahaan disimbolkan dengan "Y". Ukuranyang digunakan yaitu Return on Asset (ROA)merupakan hasil perbandingan antara laaba bersih setelah pajak dan total aset. ROA menggunakan rumus sebagai berikut:

ROA $=($ Laba Bersih Setelah Pajak/Total Aset $) \times 100 \%$

2. Variabel Independen

Variabel independen yang digunakan dalam penelitian ini adalah Likuiditas (X1) dan aktivitas (X2).

a. Likuiditas

Likuiditas merupakan perbandingan antara total utang (modal asing) dengan total modal sendiri/ekuitas (Halim, 2015).Struktur modal diukur dengan Debt to Equity Ratio (DER). Menurut Kasmir (2010) DER adalah rasio yang mengukur sejauh mana besarnya hutang dapat ditutupi oleh modal sendiri, dengan rumus sebagai berikut:

Debt to Equity Ratio = Total Utang (Debt) / Ekuitas (Equity)

b. Perputaran Persediaan

Rasio Perputaran ini ada rumus yang perlu dipahami yaitu dengan membagi Harga Pokok Penjualan (HPP) untuk suatu periode dengan rata-rata persediaan untuk periode tersebut. Karenanya sebelum melakukan perhitungan, pastikan dahulu mengetahui rumus perhitungannya Rasio Perputaran Persediaan $=$ Penjualan $/$ Rata-rata Persediaan

3. Variabel Moderasi

Efek kontingensi disebut juga efek moderasi, yaitu hubungan variabel independen terhadap variabel dependen tergantung dari nilai variabel moderasi.Variabel moderasi yang digunakan dalam penelitian ini adalah pertumbuhan penjualan disimbolkan dengan "X3".Diukur dengan selisih antara jumlah penjualan periode tahun berjalan dengan jumlah penjualan periode tahun sebelumnya dibagi jumlah penjualan periode sebelumnya. Pertumbuhan penjualan dihitung sebagai berikut:

$$
\mathrm{g}=\frac{s 1-s 0}{s 0} \times 100 \%
$$

Keterangan: $\mathrm{g}=$ Growth Sales Rate (tingkat pertumbuhan penjualan) S1 = Total Current Sales (total penjualan selama periode berjalan) $\mathrm{S} 0=$ Total Sales For Last Period (total penjualan periode yang lalu)

Teknik Analisis Data 
Untuk mengetahui pengaruh antara variabel satu dengan variabel yang lain, teknik analisis data yang digunakan adalah Analisis Regresi Moderasian. Dalam menguji dan menjelaskan apakah variabel independen berpengaruh terhadap variabel dependen dengan variabel moderasi, dapat menggunakan persamaan regresi yang diformulasikan oleh Jogiyanto (2007) sebagai berikut:

$$
Y=B_{0}+\beta_{1} X_{1}+\beta_{2} X_{2}+B_{3} X_{3}+\beta_{4} X_{1} . X_{3}+\beta_{5} X_{2} . X_{3}+e
$$

Keterangan:

Y

ß0

B1...B5

$\mathrm{X} 1$

$\mathrm{X} 2$

$\mathrm{X} 3$

e

Analisis regresi yang digunakan perlu dilakukan pengujian asumsi klasik. Asumsi klasik adalah suatu pengujian hipotesis yang digunakan suatu penelitian yang menunjukkan model regresi tersebut layak atau tidak untuk dilakukan ke pengujian selanjutnya.

\section{Uji Multikolinieritas}

Uji multikolinieritas bertujuan untuk menguji apakah model regresi ditemukan adanya kolerasi antar variabel independen (Ghozali, 2011). Model regresi yang baik seharusnya tidak terjadi korelasi diantara variabel independen agar tidak terdapat problem multikolinieritas. Untuk mengetahi ada tidaknya problem multikolinieritas dengan menentukan nilai VIP (Variance inflation Faktor), apabila nilai VIF $<10$ atau nilai Tolerance $>0,1$ berarti tidak terjadi multikolinieritas.

\section{Uji Autokorelasi}

Uji autokorelsi bertujuan untuk menguji apakad dalam model regresi ada korelasi antara kesalahan pengganggu pada periode $t$ dengan kesalahan pengganggu pada periode sebelumnya. Dilakukan dengan uji Durbin Watson (DW), kriteria yang digunakan menurut Firdaus (2010) adalah nilai DW $=1,55-2,46$. Jika nilai Durbin Watson sesuai kriteria maka tidak terjadi autokorelasi.

\section{Uji Heteroskedastisitas}

Uji ini digunakan untuk menguji apakah model regresi terjadi ketidaksamaan variance dari residual satu pengamatan ke pengamatan lain (Ghozali, 2011). Model regresi yang baik tidak 
mendeteksi heteroskedastisitas, untuk mendeteksi heteroskedastisitas adalah dengan melihat grafik plot antara nilai prediksi variabel terikat (Dependen) yaitu SRESID dan nilai residualnya ZPRED. Kriterianya jika gambar scatterplot tidak membentuk suatu gambar tertentu maka tidak terjadi heteroskedastisitas.

\section{Uji Normalitas}

Uji normalitas bertujuan untuk menguji apakah dalam model regresi, variabel pengganggu atau residual memiliki distribusi normal (Ghozali, 2011). Untuk menguji apakah residual berdistribusi normal atau tidak, test statistik yang digunakan adalah Kolmogorov Smirnov. Normal tidaknya distribusi data dapat dilihat dari nilai Asymp Sig (2-tailed), jika nilai Asymp Sig (2-tailed) > dari alpa 0.05 atau $5 \%$ maka variabel pengganggu berdistribusi normal.

\section{Pengujian Hipotesis}

Untuk menguji hipotesis yang diajukan, digunakan Uji $t$ untuk menguji dan menjelaskan apakah variabel independen secara parsial berpengaruh terhadap nilai variabel dependen. Selanjutnya digunakan untuk menguji dan menjelaskan apakah variabel moderasi memoderasi hubungan antara variabel independen terhadap variabel dependen.

\section{HASIL PENGUJIAN}

\section{Hasil Uji Asusmsi Klasik}

\section{Hasil Uji Multikolinearitas}

Hasil uji multikolonieritas menunjukkan bahwa nilai VIF semua variabel kurang dari 10, dan nilai tolerance lebih dari 0,1 sehingga tidak terjadi multikolinieritas. Artinya, tidak terjadi hubungan antar variabel bebas dalam model regresi yang digunakan.

\section{Hasil Uji Autokorelasi}

Hasil uji asumsi autokorelasi menunjukkan bahwa nilai Durbin Watson sebesar 1.598 terletak diantara 1.55-2.46 (Firdaus, 2010), hal tersebut mengindikasikan bahwa tidak terjadi autokorelasi. Artinya, model regresi yang digunakan tidak ada korelasi antara kesalahan pengganggu pada periode sekarang dengan kesalahan pengganggu pada periode sebelumnya

\section{Hasil Uji Heterokesdastisitas}

Hasil uji asumsi klasik heteroskedastisitas bertujuan menguji apakah model regresi terjadi ketidaksamaan variance dari residual satu pengamatan ke pengamatan lain (Gozali, 2011). Model regresi yang baik tidak mendeteksi heteroskedastisitas, untuk mendeteksi heteroskedastisitas adalah 
dengan melihat grafik plot, jika gambar scatterplot tidak membentuk suatu gambar tertentu maka tidak terjadi heteroskedastisitas.

\section{Hasil Uji Normalitas}

Hasil uji normalitas digunakan untuk menguji apakah dalam model regresi, variabel pengganggu atau residual memiliki distribusi normal. Untuk menguji residual berdistribusi normal atau tidak digunakan test statistic Kolmogorov smirnov. Suatu data dikatakan berdistribusi normal jika nilai Asymp Sig (2-tailed) > dari alpa 0.05 atau 5\%. Berdasarkan table 4.9 di atas nilai Asymp Sig (2-tailed) X1 sebesar 0.265, X2 sebesar 0.64, X3 sebesar 0.281, X1.X3 sebesar 0.750, X2.X3 sebesar 0.281 dan variabel Y sebesar 0.512 dimana semua nilai asymp.sig (2-tailed) tersebut melebihi 0.05 (alpha 5\%), hal ini menunjukkan bahwa variabel pengganggu/variabel yang tidak diteliti memiliki distribusi normal.

\section{Hasil Analisis Regresi Moderasian}

Hasil analisis regresi moderasian disajikan pada lampiran 4. Dari lampiran tersebut dapat dibuat persamaan regresi moderasian sebagai berikut:

$$
\begin{aligned}
& Y=B_{0}+\beta_{1} X_{1}+\beta_{2} X_{2}+\beta_{3} X_{3}+\beta_{4} X_{1} \cdot X_{3}+\beta_{5} X_{2} . X_{3}+e \\
& Y=0.246+0.650 X_{1}+0.289 X_{2}+0.386 X_{3}+0.522 X_{1} . X_{3}+0.360 X_{2} . X_{3}+e
\end{aligned}
$$

\section{Hasil Uji Hipotesis Pertama}

Hasil uji hipotesis pertama disajikan pada lampiran 4 dan diringkas pada tabel 4.10 di atas, menunjukkan bahwa nilai signifikansi uji-t atas variabel likuiditas sebesar 0.000 lebih kecil dari alpa 0.05 atau $5 \%$. Hal tersebut berarti bahwa secara parsial variabel likuiditas berpengaruh terhadap variabel return on assets (ROA). Sehingga hipotesis pertama yang menyatakan bahwa likuiditas secara parsial berpengaruh terhadap return on assets (ROA) diterima.

\section{Hasil Uji Hipotesis Kedua}

Hasil uji hipotesis kedua disajikan pada lampiran 4 dan diringkas pada tabel 4.10 di atas, menunjukkan bahwa nilai signifikansi uji-t atas variabel perputaran persediaan sebesar 0.000 lebih kecil dari alpa 0.05 atau $5 \%$. Hal tersebut berarti bahwa secara parsial variabel perputaran persediaan berpengaruh terhadap variabel return on assets (ROA). Sehingga hipotesis kedua yang menyatakan bahwa perputaran persediaan secara parsial berpengaruh terhadap return on assets (ROA) diterima.

\section{Hasil Uji Hipotesis Ketiga}

Hasil uji hipotesis ketiga disajikan pada lampiran 4 dan diringkas pada tabel 4.10 di atas, menunjukkan bahwa nilai signifikansi uji-t atas variabel pertumbuhan penjualan sebesar 0.000 lebih kecil dari alpa 0.05 atau $5 \%$. Hal tersebut berarti bahwa variabel pertumbuhan penjualan mampu 
memoderasi pengaruh variabel likuiditas terhadap variabel return on assets (ROA). Koefisien regresi (beta $=ß$ ) yang sudah di standarisasi atas variabel pertumbuhan penjualan bernilai 0.522 dan bertanda positif, sehingga dapat diartikan bahwa variabel pertumbuhan penjualan memperkuat pengaruh variabel likuiditas terhadap variabel return on assets (ROA). Dengan demikian, hipotesis ketiga yang menyatakan bahwa pertumbuhan penjualan memperkuat pengaruh likuiditas terhadap return on assets (ROA) diterima.

\section{Hasil Uji Hipotesis Keempat}

Hasil uji hipotesis keempat disajikan pada lampiran 4 dan diringkas pada tabel 4.10 di atas, menunjukkan bahwa nilai signifikansi uji-t atas variabel pertumbuhan penjualan sebesar 0.001 lebih kecil dari alpa 0.05 atau 5\%. Hal tersebut berarti bahwa variabel pertumbuhan penjualan mampu memoderasi pengaruh variabel perputaran persediaan terhadap variabel return on assets (ROA). Koefisien regresi (beta= $=$ ) yang sudah di standarisasi atas variabel pertumbuhan penjualan bernilai 0.360 dan bertanda positif, sehingga dapat diartikan bahwa variabel pertumbuhan penjualan memperkuat pengaruh variabel perputaran persediaan terhadap variabel Return On Assets (ROA). Dengan demikian, hipotesis keempat yang menyatakan bahwa pertumbuhan penjualan memperkuat pengaruh Perputaran persediaan terhadap Return On Assets (ROA) diterima.

\section{PEMBAHASAN}

\section{Pengaruh Likuiditas Terhadap Return On Assets (ROA)}

Hasil penelitian ini menunjukkan bahwa nilai signifikansi uji-t variabel likuiditas sebesar 0.000 lebih kecil dari alpa 0.05 atau 5\% dengan koefisien regresi yang sudah di standarisasi sebesar 0.650 dan bertanda positif. Sehingga jika variabel likuiditas dinaikkan 1 satuan, maka nilai variabel Return On Assets (ROA) akan naik 0.650 satuan. Hal ini mengindikasikan bahwa jika tingkat likuiditas perusahaan bagus maka nilai Return On Assets (ROA) juga akan naik. Hasil penelitian ini mendukung penelitian yang dilakukan oleh M. Iqbal Notoatmojo (2018), Ika Eris Sihombing (2017). Likuiditas yaitu kemampuan perusahaan untuk memenuhi kewajiban keuangannya pada saat ditagih. Menurut syamsuddin (2001: 41 ) menyatakan bahwa likuiditas merupakan indikator mengenai kemampuan perusahaan untuk membayar semua kewajiban finansial jangka pendek pada saat jatuh tempo dengan menggunakan aktiva lancar yang tersedia. Selanjutnya Munawir (2004:31) menyatakan bahwa likuiditas adalah menunjukan kemampuan suatu perusahaan untuk memenuhi kewajiban keuangannya yang harus segera dipenuhi, atau kemampuan perusahaan untuk memenuhi kewajiban 
keuangan pada saat ditagih. Penelitian ini menunjukkan bahwa semakin tinggi tingkat likuiditas perusahaan, maka perusahaan mampu untuk membayar kewajiban finansial perusahaan.

Munawir (2002) Current Ratio (CR) menunjukkan tingkat keamanan kreditor jangka pendek.Current Ratio (CR) yang terlalu tinggi menunjukkan kelebihan uang kas atau aktiva lancar lainya dibandingkan dengan yang dibutuhkan sekarang. Dari hasil pengukuran rasio, apabila rasio lancar rendah dapat dikatakan bahwa perusahaan kurang modal untuk membayar utang. Namun, apabila hasil rasio tinggi, belum tentu perusahaan dalam kondisi baik. Bisa saja karena kas tidak digunakan sebaik mungkin untuk tujuan perusahaan mendapat laba yang maksimal. Berdasarkan lampiran dapat diketahui bahwa likuiditas perusahaan yang dijadikan penelitian menunjukkan nilai diatas 1. Artinya perusahaan mampu membayar kewajibanya apabila perusahaan tersebut dilikuidasikan. Dari pembahasan diatas dapat disimpulkan bahwa untuk mendapatkan nilai Return On Assets (ROA) yang tinggi, maka perusahaan harus memaksimalkan likuiditas perusahaan. karena dengan naiknya tingkat likuiditas tersebut Return On Assets (ROA) akan mengalami peningkatan.

\section{Pengaruh Perputaran Persediaan Terhadap Return On Assets (ROA)}

Hasil penelitian ini menunjukkan bahwa nilai signifikansi uji-t variabel perputaran persediaan sebesar 0.000 lebih kecil dari alpa 0.05 atau 5\% dengan koefisien regresi yang sudah di standarisasi sebesar 0.289 dan bertanda positif. Sehingga jika variabel perputaran persediaan dinaikkan 1 satuan, maka nilai variabel Return On Assets (ROA) akan naik 0.289 satuan. Hal ini mengindikasikan bahwa jika perputaran persediaan tinggi atau meningkat, maka nilai Return On Assets (ROA) pasti juga akan naik. Kasmir (2010:264) persediaan adalah sejumlah barang yang harus disediakan oleh perusahaan pada suatu tempat tertentu. Artinya adanya sejumlah barang yang disediakan perusahaan guna memenuhi kebutuhan produksi atau penjualan barang dagangan. Sedangkan menurut Bambang Riyanto (2001:69) Inventory atau persediaan barang sebagai elemen yang utama dari modal kerja merupakan aktiva yang selalu dalam keadaan berputar,i mana secara terus menerus mengalami perubahan. Masalah investasi dalam inventory merupakan masalah pembelanjaan aktif, seperti halnya investasi dalam aktiva-aktiva lainnya. Masalah penetuan besar investasi atau alokasi modal dalam inventory mempunyai efek yang lansung terhadap keutungan perusahaan. Kesalahan dalam penetapan besarnya investasi dalam inventory akan menekan keuntungan perusahaan. Adanya investasi dalam inventory yang terlalu besar dibandingkan dengan kebutuhan akan memperbesar beban bunga, memperbesar biaya penyimpanan dan pemiliharaan di gudang, memperbesar 
kemungkinan kerugian karena kerusakan, turunnya kualitas, sehingga semuanya ini akan memperkecil keutungan perusahaan.

Penelitian ini mendukung hasil penelitian Hasil peneitian ini mendukung penelitian sebelumnya oleh Farhana,dkk (2016). Yang menyimpulkan secara parsial perputaran persediaan berpengaruh signifikan positif terhadap profitabilitas. Kesimpulan dari pernyataan di atas dapat dinyatakan bahwa, jika perusahaan ingin menaikkan Return On Assets (ROA), maka perusahaan harus memperhatikan variabel perputaran persediaan. Rasio perputaran persediaan digunakan untuk mengukur aktivitas atau likuiditas dari persediaan perusahaan. Maksudnya yaitu mengukur tingkat efisiensi suatu perusahaan dalam mengelola dan menjual persediaan yang dimiliki oleh perusahaan. Efektifitas manajemen persediaan ditunjukan oleh tingginya perputaran persediaan dalam satu tahun. Sedangkan pengendalian atas perediaan yang kurang efektif ditunjukan dengan rendahnya perputaran persediaan dalam satu tahun. Rasio ini digunakan untuk mengetahui seberapa tingkat efektivitas perusahaan dalam mengelola persediaannya. Semakin tinggi tingka perputarannya maka semakin efektif juga pengelolaan pesediaannya sehinggap laba yang diperoleh juga akan meningkat.

\section{Pertumbuhan Penjualan Memperkuat Pengaruh Likuiditas Terhadap Return On Assets (ROA)}

Hasil penelitian ini menunjukkan bahwa nilai signifikansi uji-t atas variabel pertumbuhan penjualan lebih kecil dari alpa 0.05 atau 5\% dengan Koefisien regresi (beta=ß) yang sudah di standarisasi atas variabel pertumbuhan penjualan bernilai 0.522 dan bertanda positif, sehingga dapat diartikan bahwa variabel pertumbuhan penjualan memperkuat pengaruh variabel likuiditas terhadap variabel return on assets (ROA). Penelitian ini mendukung penelitian sebelumnya oleh Supanji Setiawan, Susilowati (2018) yang menyimpulkan pertumbuhan penjualan secara parsial berpengaruh positif signifikan terhadap profitabilitas perusahaan.

Penelitian ini di dukung teori oleh Kesuma (2009) juga menyatakan bahwa sales growth adalah kenaikan jumlah penjualan dari tahun ke tahun atau dari waktu ke waktu. Pertumbuhan penjualan tinggi, maka akan mencerminkan pendapatan perusahaan yang juga meningkat. Sedangkan Mayangsari (2001) perusahaan yang penjualannya tumbuh secara besar dan dapat mengelola biaya dengan efisien memiliki kemungkinan untuk memperoleh laba yang cukup tinggi sehingga perusahaan memiliki kecukupan dana untuk membayar hutang yang terjadi dalam rangka kelangsungan hidup perusahaan. Berdasarkan teori di atas, perusahaan yang mengalami pertumbuhan penjualan pasti juga mengalami peningkatan aset lancar. Dengan adanya kenaikan pada aset lancar tersebut, maka tingkat likuiditas perusahaan juga akan naik. Semakin baik tingkat 
Dio Irsa Asy Sams, Pengaruh Likuiditas Dan Perputaran PersediaAn Terhadap Return On Assets

(Roa) Dengan Pertumbuhan Penjualan Sebagai Variabel Moderasi Pada Perusahaan Makanan Dan

Minuman Periode 2015-2018

likuiditas perusahaan akan memperlancar kegiatan kelangsungan perusahaan untuk mendapatkan laba dengan maksimal.

Pertumbuhan Penjualan Memperkuat Pengaruh Perputaran Persediaan terhadap Return On Asset (ROA)

Hasil penelitian ini menunjukkan bahwa nilai signifikansi uji-t atas variabel pertumbuhan penjualan sebesar lebih kecil dari alpa 0.05 atau 5\%. Hal tersebut berarti bahwa variabel pertumbuhan penjualan memoderasi pengaruh variabel perputaran persediaan terhadap variabel return on assets (ROA). Koefisien regresi (beta= $\$$ ) yang sudah di standarisasi atas variabel pertumbuhan penjualan bernilai 0.360 dan bertanda positif, sehingga dapat diartikan bahwa variabel pertumbuhan penjualan memperkuat pengaruh variabel perputaran persediaan terhadap variabel Return On Assets (ROA). Hal ini mengindikasikan jika perusahaan mengalami pertumbuhan penjualan, maka perputaran persediaan juga akan tinggi.Penelitian ini mendukung penelitian sebelumnya oleh Farhana,dkk (2016), Amrita Maulidia Rahmah, wayan cipta, fridayana Yudiatmaja (2016). Penelitian ini di dukung teori Kasmir (2010:264) persediaan adalah sejumlah barang yang harus disediakan oleh perusahaan pada suatu tempat tertentu. Artinya adanya sejumlah barang yang disediakan perusahaan guna memenuhi kebutuhhan produksi atau penjualan barang dagang. Adanya pertumbuhan penjualan perusahaan akan mempengarui tingkat perputaran persediaan karena dengan meningkatnya penjualan maka perputan persediaan juga meningkat. Masalah penentuan besar investasi atau alokasi modal dalam inventory mempunyai efek yang langsung terhadap keuntungan perusahaan. Untuk itu perusahaan harus mengelola perputaran dengan efisien agar pendapatan perusahaan bisa dimaksimalkan.

\section{KESIMPULAN}

Berdasarkan pengujian dan penjelasan yang telah dilakukan, dapat disimpulkan bahwa Secara parsial variabel likuiditas berpengaruh signifikan positif terhadap Return On Assets (ROA). Secara parsial variabel perputaran persediaan berpengaruh signifikan positif terhadap Return On Assets (ROA). Pertumbuhan penjualan memperkuat pengaruh Likuiditas terhadap Return On Assets (ROA).Pertumbuhan penjualan memperkuat pengaruh perputaran persediaan terhadap Return On Assets (ROA).

\section{DAFTAR PUSTAKA}


Abdul, Halim. 2015. Auditing (Dasar-dasar Audit Laporan Keuangan). Jilid 1. Edisi Kelima. UPP STIM YKPN: Yogyakarta.

Abdul, Halim. 2015. Auditing (Dasar-dasar Audit Laporan Keuangan). Jilid 1. Edisi Kelima. UPP STIM YKPN: Yogyakarta.

Dunia Firdaus A. 2010. Ikhtisar Lenkap Pengantar Akuntansi Edisi Ketiga. Jakarta : Fakultas Ekonomi Universitas Indonesia

Farhana, Cintya Dewi., Gede Putu Agus J. \& I Wayan S. 2016. Pengaruh Perputaran Persediaan dan Pertumbuhan Penjualan Terhadap Profitabilitas Pada PT Ambara Mdya Sejati Di Singaraja Tahun 2012-2014. E-Journal Bisma Universitas Pendidikan Ganesha, Vol 4.

Ghozali, Imam. 2011. Aplikasi Analisis Multivariat Dengan Program SPSS. Semarang : Badan Penerbit Universitas Diponegoro

Hanafi, Mamduh M dan Abdul Halim. 2000. "Analisis Laporan Keuangan". UPP AMP YKPN: Yogyakarta. Hani, Syafrida. 2015. Teknik Analisa Laporan Keuangan. Medan: UMSU PRESS.

Hani, Syafrida. 2015. Teknik Analisa Laporan Keuangan. Medan: UMSU PRESS.

I Dewa Gd Gina Sanjaya. 2015. Pengaruh Likuiditas dan Aktivitas Terhadap Profitabilitas Pada PT PLN (Persero). Vol 12, Nomor 1, Januari Juni 2015.

Jogiyanto, H. 2007. Model Kesuksesan Sistem Teknologi Informasi. Yogyakarta: Andi.

Kasmir. (2010). Pengantar Manajemen Keuangan. Jakarta: Kencana Prenada Media Group.

Nafarin,M. 2007. Penganggaran Perusahaan. Edisi Ketiga. Jakarta: Salemba Empat

Nafarin,M.2007.Penganggaran Perusahaan. Jakarta: Salemba Empat.

Riyanto, Bambang. 2008. Dasar-dasar Pembelanjaan Perusahaan. Yogyakarta: GPFE

S. Munawir,2007. Analisa Laporan Keuangan. Liberty, Yogyakarta.

S. Munawir. 2004. Analisis Laporan Keuangan, Edisi Ke-4, Liberty, Yogyakarta. Ikatan Akuntansi Indonesia (IAI). 2004. Pernyataan Standar Akuntansi Keuangan (PSAK). Jakarta: Salemba Empat. Sartono, Agus. 2010. Manajemen Keuangan Teori dan Aplikasi. Yogyakarta: BPFEE 